\title{
75-lecie urodzin Profesora zwyczajnego Zygmunta Ruty
}

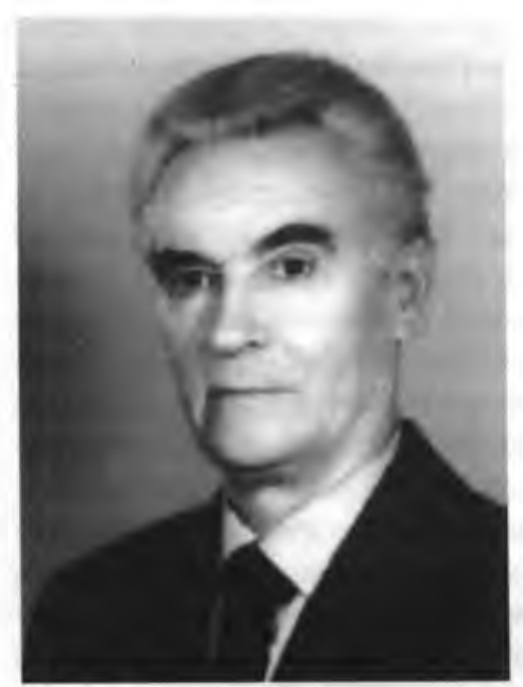

Prof. zw. dr hab. Zygmunt Ruta urodził się 10 lipca 1932 r. w Borusowej (pow. Dąbrowa Tarnowska) w rodzinie Jana i Zofii z domu Sobota. Szkołę podstawową ukończył w rodzinnej miejscowości, a następnie uczęszczał do znanego z humanistycznych tradycji I Liceum Ogólnokształcącego im. K. Brodzińskiego w Tarnowie, gdzie w 1951 r. złożył równocześnie egzamin dojrzałości i egzamin uzupełniający z przedmiotów pedagogicznych uzyskując $w$ ten sposób uprawnienia do nauczania w szkole podstawowej. Zgodnie z nakazem pracy obją $\mathrm{w} 1951$ r. stanowisko nauczyciela w szkole ćwiczeń przy Liceum Pedagogicznym w Tarnowie. Wkrótce jednak, bo już w listopadzie $1952 \mathrm{r}$., został powołany do odbycia zasadniczej służby wojskowej. Po jej ukończeniu podjął pracę pedagogiczna $w$ Młodzieżowym Domu Kultury w Tarnowie i rozpoczął w 1955 r. zaoczne studia historyczne w Wyższej Szkole Pedagogicznej w Warszawie. Jednak po ukończeniu I roku przeniósł się do WSP w Krakowie na studia dzienne. Dyplom magistra historii uzyskał w 1959 r. po obronie pracy $\mathrm{z}$ zakresu szkolnictwa i oświaty $\mathrm{w}$ okresie staropolskim, wykonanej w seminarium prof. dr. Ignacego Zarębskiego, znanego badacza dziejów wczesnego Odrodzenia. Praca ta, znacznie uzupełniona i poszerzona, została opublikowana w roku 1962 pt. $Z$ problemów oświaty i szkolnictwa w Tarnowie do końca XVII wieku. Problematyką historii kultury i szkolnictwa zainteresował Z. Rutę przede wszystkim Mistrz, prof. I. Zarębski, ale na pogłębienie tych zainteresowań w dużym stopniu wpłynął prof. Leszek Hajdukiewicz z Uniwersytetu Jagiellońskiego, który służył mu radą i w pełni akceptowal kierunki badań i poziom prac naukowych, także z zakresu dobrze rozumianej regionalistyki.

Prof. Z. Ruta od 1959 r. związał się swoim stażem naukowym z WSP w Krakowie, wchodząc tym samym w krakowskie środowisko historyczne, które ma szczególnie piękne tradycje badawcze na polu polskiej oświaty i kultury edukacyjnej. WSP w Krakowie $z$ powodzeniem kontynuowała te historyczne tradycje badawcze, w czym niemała zasługa profesora Z. Ruty. W Katedrze, kierowanej przez Niego, sa prowadzone i powstają zespołowe prace badawcze. Uczelniany ośrodek promieniuje na regionalne ośrodki kulturalno-oświatowe Małopolski, inicjując i realizując w nich badania regionalne. 
Jako asystent w Katedrze Historii Polski już od 1959 r. prowadził badania z dziedziny historii oświaty i wychowania, podejmując zwłaszcza temat rozprawy doktorskiej, wiążący się z dziejami oświaty w Małopolsce okresu staropolskiego i rolą Uniwersytetu Krakowskiego w procesie organizowania i podnoszenia poziomu oświaty na tym terenie. Efektem działalności naukowo-badawczej w tym zakresie, niezależnie od kilku artykułów, była źródłowa monografia, stanowiąca podstawę do uzyskania stopnia doktora nauk humanistycznych w 1967 r., która została opublikowana pt. Szkoly tarnowskie $w X V-X V I I I w$. w ramach wydawnictw PAN. Dwie kolejne prace zostały poświęcone dziejom oświaty, szkolnictwa i wychowania w powiecie dąbrowskim do końca XVIII w. oraz w dwudziestoleciu 1918-1939. W zainicjowanej przez siebie i redagowanej (wspólnie z F. Kirykiem) monografii zbiorowej pt. Dabrowa Tarnowska. Zarys dziejów miasta i powiatu (1974) sięgnął autor i tym razem do nietkniętego niemal dotąd piórem badacza tematu, wydobywając na światło dzienne nie tylko nowe fakty i zjawiska, ale także społecznie ważne w procesie kształtowania samowiedzy i edukacji historycznej poznawcze, patriotyczne, obywatelskie elementy umiłowania i szacunku dla tradycji własnego regionu. W pracach tych, rehabilitując kwestionowaną niekiedy rolę i znaczenie regionalistyki, potrafił prof. $Z$. Ruta przekonywająco obronić ten gatunek pisarski, słusznie upatrując w nim skuteczny instrument pedagogiki społecznej, która nic nie tracąc ze swych walorów poznawczych pozwala specjaliście nawiązać żywy i bezpośredni kontakt z jego czytelnikiem. Temu samemu celowi służy działalność recenzyjna $Z$. Ruty, pilnego obserwatora i sumiennego kronikarza regionalnego ruchu naukowego południowej Małopolski, w której życzliwie, ale i bez taryfy ulgowej omawia inicjatywy wydawnicze Tamowa, Jasła, Nowego Sącza, Krosna, Miechowa, Jaworzna, Myślenic, służąc autorom życzliwą rada, ale i shusznie stawiając sobie wymagania naukowej rzetelności i szacunku dla źródeł.

Prawie równocześnie $\mathrm{z}$ ukończeniem pracy o szkolnictwie przedrozbiorowym przystapił prof. Z. Ruta do studiów nad dziejami Tarnowa w XIX i XX w. Niemal monograficznych opracowań doczekały się edukacyjne zakłady tarnowskie (gimnazja i kolonie akademickie dawniejsze i gimnazja z okresu międzywojnia, seminaria nauczycielskie męskie i żeńskie, szkolnictwo średnie żydowskie, tajne nauczanie w okresie okupacji hitlerowskiej itp.), syntetyczne opracowania szkolnictwa i stosunków kulturalnych zostały zawarte w trzytomowej zbiorowej monografii Tarnów. Dzieje miasta i regionu (1981-1983). Podobnie ma się rzecz w odniesieniu do szkolnictwa i życia kulturalnego kilku miast Ziemi Tarnowskiej.

W tym miejscu trzeba zwrócić uwagę na rolę prof. Z. Ruty w inicjowaniu i redagowaniu regionalnych monografii zbiorowych miast Małopolski i zbiorowych wydawnictw naukowych. Dorobek Jego w tej mierze jest imponujący. Prof. Z. Ruta był bowiem inicjatorem, organizatorem i współredaktorem obszernych monografii Tarnowa, Dąbrowy Tarnowskiej, Bochni, Nowego Sącza i gminy Wierzchosławice. Te zbiorowe monografie tamtejszych miast i regionów należą do trwałych i pięknych osiągnięć badawczych, także jeżeli chodzi o wgląd w oświatowo-kulturalną przeszłość i teraźniejszość. Pod Jego redakcją ukazało się także pięć tomów Prac Historycznych i Pedagogicznych, cztery Prace z Historii Oświaty i Wychowania, oraz jedenaście tomów „Rocznika Komisji Nauk Pedagogicznych" PAN, Oddział w Krakowie. Ma wreszcie udane doświadczenia edytorskie jako wydawca źródeł do dziejów macierzystej Uczelni. Udział w realizacji i wysiłek 
włożony w organizowanie i redagowanie tego rodzaju opracowań zespołowych to niepomierny trud, który trzeba w pełni docenić.

Osobne miejsce na tym polu zajmują studia i monografie Z. Ruty poświęcone szkolnictwu krakowskiemu i oświatowemu oddziaływaniu Uniwersytetu Krakowskiego. Zaczęło się to od badań nad rolą terenowych kolonii akademickich Uniwersytetu w czasach staropolskich. Zwłaszcza źródłowe repertorium Nauczyciele kolonii akademickich Uniwersytetu Krakowskiego w XVIII wieku (1968) zachowało swoją nieprzemijającą wartość w piśmiennictwie naukowym. Zainteresowanie koloniami akademickimi Uniwersytetu Krakowskiego ujawnił Z. Ruta również w latach późniejszych. W obszernej rozprawie z roku 1989 przedstawił dzieje kolonii akademickiej w Nowym Korczynie, w roku 1992 w źródłowym studium omówił powstanie i rozwój kolonii akademickiej i szkoły wydziałowej w Białej Podlaskiej (wspólnie z J. Rysiem).

Nie porzucając tematyki regionalnej ok. roku 1976 wszedł prof. Z. Ruta na obszar nowszych i najnowszych dziejów oświaty w skali, chciałoby się powiedzieć, globalnej, gdyby ów poszerzony zakres nie dotyczył głównie regionu krakowskiego. W $1980 \mathrm{r}$. opublikował obszerną monografię pt. Szkolnictwo powszechne w Okregu Szkolnym Krakowskim w latach 1918-1939, poprzedzoną studium „nad koncepcją szkoły powszechnej na ziemiach polskich w okresie I wojny światowej". Praca ta była podstawą przewodu habilitacyjnego w Wydziale Humanistycznym WSP w Krakowie, którego Rada Wydziału nadała Mu stopień naukowy doktora habilitowanego w 1979 r. Wreszcie poświęcał Z. Ruta także uwagę badawczą odbudowie szkolnictwa krakowskiego po II wojnie światowej (dwie rozprawy z 1976 r. i rozprawa o kształceniu nauczycieli z 1980 r.).

Z kolei opracowania dotyczące kształcenia nauczycieli objęły już jako pole badawcze cały kraj, a nie tylko region Małopolski. Miał on szczególny powód do zajęcia się tą problematyką nie tylko jako historyk edukacji, ale jako dhugoletni nauczyciel akademicki Uczelni, która w okresie 60-letniej działalności przykładała wielką uwagę do wypracowania nowoczesnego modelu kształcenia nauczycieli. Owocem badań w tym zakresie jest m.in. zbiorowa monografia pt. Ksztalcenie nauczycieli w Polsce Ludowej 1945-1975 pod redakcją Jerzego Jarowieckiego, Bogdana Noweckiego i Zygmunta Ruty (1983). Obok wkładu redaktorskiego $Z$. Ruta jest $w$ tej pracy autorem części odnoszącej się do kształcenia nauczycieli na poziomie średnim i w ramach pedagogium, wyższych kursów nauczycielskich i instytutów pedagogicznych. Liceom pedagogicznym poświęcał Z. Ruta uwage $\mathrm{i} w$ innych pracach dokumentacyjnych (1983).

Jedną z ostatnich źródłowych monografii Z. Ruty z tego obszaru badawczego jest praca pt. Prywatne szkoty średnie ogólnoksztalcace $w$ Krakowie $i$ województwie krakowskim w latach 1932-1939 (1990). Książka ta wkroczyła na tereny oświatowe niemal zupełnie naukowo nierozpoznawalne, a przecież szkolnictwo prywatne odgrywało istotną rolę w międzywojennej edukacji (rzeczywistość szkolna powraca dzisiaj do tego zjawiska). Podstawa źródłowa monografii (głównie sprawozdania z wizytacji) pozwoliła Z. Rucie sięgać w wewnętrzne życie i funkcjonowanie takich szkół. Książkę cechuje zwięzłość i jasność wykładu, a w okresie jej opublikowania była unikatową w naszej literaturze historyczno-pedagogicznej. $\mathrm{Na}$ teren międzywojennej sytuacji szkolnictwa powszechnego powraca z kolei inne studium Z. Ruty z 1993 r., mianowicie Szkolnictwo powszechne w województwach poludniowych w latach 1918-1928. 
W 1999 r. Z. Ruta opracował (wspólnie z J. Rysiem) dzieje najstarszej średniej szkoły tarnowskiej, jaką jest I Liceum Ogólnokształcące im. K. Brodzińskiego w Tarnowie. Natomiast w 2003 r. pod jego redakcja (wspólnie z R. Ślęczka) ukazała się Księga poświęcona pamięci Profesora Czesława Majorka, wybitnego historyka edukacji i dydaktyki historii, cenionego w środowisku historyków wychowania i pedagogów nie tylko w kraju, ale za granica.

$\mathrm{Na}$ uwagę w dorobku naukowym prof. $Z$. Ruty zasługują również erudycyjne artykuły biograficzne postaci związanych z dziejami oświaty, pisane głównie dla Polskiego Stownika Biograficznego.

Wreszcie jest prof. Z. Ruta wydawcą źródeł do dziejów i dziejopisem swojej macierzystej Uczelni - Wyższej Szkoły Pedagogicznej. Najpierw w roku 1981 ukazała się pod jego redakcją obszerna publikacja pt. Wyższa Szkola Pedagogiczna im. Komisji Edukacji Narodowej $w$ Krakowie $w$ latach 1946-1981 (jako autor Z. Ruta wspólnie z C. Majorkiem opracował w niej powstanie i rozwój organizacyjny Uczelni). Na plus tej zbiorowej monografii i jej Redaktora trzeba zapisać, że ksiega nie ma jedynie charakteru okolicznościowego - 35 lat działalności Szkoły - ale rzeczywiście stara się ukazywać, w naukowym źródłowym ujęciu, życie, w którym znajdowały swoje odbicie wszelkie meandry w zakresie naszych koncepcji kształcenia nauczycieli po II wojnie światowej. Kolejna zbiorowa monografia pod Jego redakcja pt. Wyższa Szkola Pedagogiczna im. Komisji Edukacji Narodowej w Krakowie w latach 1982-1996 została wydana w związku z jubileuszem 50 -lecia. Dobrą konfrontacje dla tych monografii stanowią wydane przez Z. Rutę najpierw w dwóch tomach Źródla do dziejów Wyższej Szkoły Pedagogicznej im. Komisji Edukacji Narodowej w Krakowie w latach 1946-1981, cz. I-II (Kraków 1982-1983), a następnie trzeci tom Źródła do dziejów Wyższej Szkoly Pedagogicznej w Krakowie w latach 1982-1996 (Kraków 1996) (wspólnie z J. Krukowskim). Trudno przecenić takie wydawnictwo źródłowe. Ma ono znaczenie nie tylko lokalne, lecz daje zainteresowanemu badaczowi szerszy wgląd w politykę w dziedzinie nauki, szkolnictwa wyższego i w przemiany w zakresie systemu kształcenia nauczycieli w Polsce Ludowej.

Gdyby w ocenie dorobku naukowego przyjąc kryteria ilościowe, to liczba prac prof. Z. Ruty przekroczyła 100, w tym 4 książki, kilka wydawnictw źródłowych i kilkanaście opracowań redakcyjnych. Nie liczba wszakże jest ważna, lecz jakość publikowanych prac $\mathrm{i}$ ich rola w poszerzaniu wiedzy historyczno-pedagogicznej. One stanowią przecież trwała pozycje w naukowym życiorysie prof. Z. Ruty. Są to publikacje bez wyjątku źródłowe, gdyż autor ich nie posuwał się po utartych szlakach przy badaniach nad historią oświaty rodzinnych stron ani podczas opracowywania szkolnictwa powszechnego, średniego ogólnokształcącego i pedagogicznego, a tym bardziej w czasie kompletowania źródeł do historii krakowskiej Wyższej Szkoły Pedagogicznej.

$\mathrm{Z}$ pewnością nie wszystkie osiągnięcia naukowe prof. zw. Z. Ruty zostały tutaj odnotowane i zasygnalizowane. Ale już te, na które zwróciliśmy uwagę, pozwalają - jak sądzimy - ocenić jego poważny i trwały wkład w polską historiografię oświatową. Dobrze też charakteryzują one Z. Rutę jako historyka. Jest to nade wszystko historyk doceniający konieczność i pożytek żmudnych i rozległych kwerend archiwalnych. Dotyczy to tak dalszej przeszłości (np. gdy bada funkcjonowanie kolonii akademickich Uniwersytetu Krakowskiego), jak i dziejów nowszych i najnowszych (np. gdy zajmuje się szkolnictwem w dwudziestoleciu międzywojennym, czy gdy dokumentuje sieć i funkcjonowanie 
liceów pedagogicznych w Polsce Ludowej). Jego pisarstwo naukowe znamionują udane analizy źródłoznawcze, lecz równocześnie umiejętność syntezy obszernej tematyki (przykłady tego znajdujemy chociażby w monografiach poświęconych miastom regionu tarnowskiego). Zgodnie $\mathrm{z}$ dobrą tradycją krakowskiego środowiska historyczno-oświatowego problemy edukacyjne są ukazywane na szerszym tle kulturalnym i społeczno-gospodarczym. To prowadzi do zarysu funkcji społecznej badanych instytucji i placówek szkolno-oświatowych. Jednocześnie - obok obrazu funkcjonowania społeczno-kulturalnego szkół - mamy próby dociekań podstaw przeobrażeń programowych i realizowanych koncepcji edukacyjnych. Przykładem wspomnianego społeczno-kulturalnego funkcjonowania edukacji może być w twórczości prof. Z. Ruty ukazywanie - w odleglejszej przeszłości - procesów i mechanizmów kształtowania się inteligencji Małopolski w kręgu wpływów i oddziaływania Akademii Krakowskiej, w bliższej zaś przeszłości - roli szkolnictwa pedagogicznego, jak i szkolnictwa prywatnego. Na podkreślenie zasługuje „nastawienie regionalne" $Z$. Ruty, w najlepszym tego słowa znaczeniu. Jego studia i monografie oraz regionalne syntezy, Jego aktywność w regionalnych towarzystwach kulturalno-oświatowych są z pewnością świadomym wyborem i docenieniem nastawienia na inspirację badań regionalnych, na kształtowanie na tej drodze społecznej samowiedzy historycznej. Jest to jeden $\mathrm{z}$ chwalebnych przykładów realizacji społecznych powinności historyka i wiedzy historycznej. Dołączają się do tego nastawienie i umiejętności prof. Z. Ruty organizowania i owocnego realizowania prac zespołowych. Dokonań w Jego dorobku naukowym - jak już podkreślaliśmy - jest sporo. Rzutuje to też na jego postawę jako nauczyciela akademickiego. Umiał skupić wokół siebie i zainteresować problematyką historyczno-oświatową studentów, magistrantów i doktorantów. Należy docenić tę edukację historyczną w środowisku kształcenia kadr nauczycielskich, jakim to środowiskiem dla prof. Z. Ruty była Wyższa Szkoła Pedagogiczna w Krakowie.

Prof. Z. Ruta należy do zasłużonych i oddanych sprawie polskiej oświaty nauczycieli akademickich. W krakowskiej WSP przeszedł wszystkie szczeble kariery akademickiej od asystenta, adiunkta, docenta do profesora. Kształtowaną przez lata ciężkiej pracy nad sobą Jego osobowość charakteryzowała zawsze pracowitość, rzetelność i systematyczność w podejmowaniu i wykonywaniu zadań dydaktycznych i prac badawczych, wynikające z poważnego traktowania spełnianej roli nauczycielskiej i głębokiego poczucia odpowiedzialności za słowo mówione i pisane.

Wcale pokaźnie przedstawiaja się również osiagnięcia prof. Z. Ruty w zakresie kształcenia nauczycieli i młodszej kadry naukowej, a także w przygotowaniu programów nauczania $z$ historii wychowania oraz historii nauki i techniki, czy też w pracy społecznej na rzecz macierzystej Uczelni. Prof. Z. Ruta wykształcił kilkadziesiąt roczników studentów dziennych i zaocznych. Jest promotorem około 300 magistrów pedagogiki i historii oraz 6 doktorów nauk humanistycznych. Uważał, że do podstawowych obowiązków samodzielnych pracowników nauki, zwłaszcza profesorów, należy kształcenie kadry naukowej. Dlatego chętnie uczestniczył jako recenzent $w$ wielu przewodach doktorskich i habilitacyjnych, zarówno w swojej Uczelni, jak i w różnych ośrodkach naukowych $w$ kraju. Przygotowywał też oceny dorobku naukowego w związku z ubieganiem się pracowników o tytuł naukowy profesora lub stanowisko profesora w uczelniach wyższych w Polsce. Do rozwoju naukowego nauczycieli akademickich w uniwersytetach i wyż- 
szych szkołach pedagogicznych przyczyniał się też przez pisanie recenzji wydawniczych prac na stopień, monografii oraz zbiorowych wydawnictw naukowych.

Od początku zatrudnienia w WSP w Krakowie był żywo zaangażowany we wszystkich pracach naukowo-badawczych, organizacyjnych i wychowawczych. I tak, był kolejno: delegatem młodszych pracowników do Rady Wydziału, rzecznikiem dyscyplinarnym rektora ds. studentów, przewodniczącym Rady Szkoły ds. Młodzieży, a szczególnie dużo czasu - po uzyskaniu stanowiska samodzielnego pracownika nauki - zajmowała mu praca w Senacie Uczelni i jego komisjach. W latach 1980-1990 jako członek Senatu przewodniczył Senackiej Komisji ds. Opracowania Statutu Szkoły, który został wdrożony od 1 października 1983 r. Komisja ta przygotowała także regulaminy wyborcze rektora, prorektorów, dziekanów, prodziekanów, dyrektorów instytutów, kierowników katedr i zakładów oraz dyrektora Biblioteki Głównej. Był także dwukrotnie przewodniczącym Uczelnianej Komisji Wyborczej. Przez dwie kadencje był wiceprzewodniczącym Senackiej Komisji ds. Wydawniczych WSP w Krakowie. W tym czasie przygotowany został regulamin i zasady wydawnicze Wydawnictwa Naukowego, które wcielono wówczas w życie. Prof. Z. Ruta ma duże zasługi jako współorganizator Zrzeszenia Absolwentów WSP w Krakowie, pełniąc przez 6 lat funkcje wiceprezesa i prezesa Zarządu. Jako członek ZNP (od 1951 r.) brał udział w pracach Prezydium Rady Zakładowej, a także był członkiem Komisji Rewizyjnej tejże Rady.

Prof. Z. Ruta jest współtwórcą i wieloletnim kierownikiem Zakładu Historii Oświaty i Wychowania, a w latach 1982-1997 był kierownikiem Katedry Historii Oświaty i Wychowania. Jest członkiem kilku towarzystw naukowych, należy m.in. do Komisji Nauk Pedagogicznych Oddziału PAN w Krakowie, w latach 1987-1990 jej wiceprzewodniczącym, od 1990 r. przewodniczy Komitetowi Redakcyjnemu „Rocznika” i prac monograficznych tej Komisji, Polskiego Towarzystwa Historycznego, Towarzystwa Przyjaciół Ziemi Tarnowskiej, Stowarzyszenia Miłośników Dąbrowy Tarnowskiej, Rady Naukowej Stacji PTH w Przemyślu i Nowym Sączu.

Jego oddanie sprawie kształcenia nauczycieli i polskiej oświacie w ogóle, a także Jego kompetencje naukowe, dydaktyczne i organizacyjne znalazły uznanie władz. Prof. Z. Ruta otrzymał pięciokrotnie nagrodę Ministra Nauki, Szkolnictwa Wyższego i Techniki oraz liczne nagrody i listy Rektora, a także tytuł honorowy „Zasłużony Nauczyciel PRL”. Odznaczony został Złotym Krzyżem Zasługi, Krzyżem Kawalerskim Orderu Odrodzenia Polski, Medalem Komisji Edukacji Narodowej, Medalem 40-lecia PRL, Złotą Odznaką ZNP i Odznaką 50 lat w ZNP, Medalem za Zasługi dla Miasta Tarnowa, medalem 700 -lecia Miasta Nowego Sącza i Złotą Odznaką za Zasługi dla Ziemi Krakowskiej.

Kończąc uwagi o sylwetce naukowej prof. Z. Ruty trzeba podkreślić, że należy on do grona znanych w całym kraju historyków edukacji, jest organizatorem aktywnego ruchu naukowego w zakresie historiografii pedagogicznej, co się wyraża m.in. w inicjowaniu i redagowaniu zbiorowych wydawnictw naukowych, jest badaczem samodzielnym i twórczym o dużym dorobku naukowym, imponującym ścisłością i trzeźwością sądów oraz umiejętnościami organizacyjnymi. 